\title{
Financial Stress Spillover across Asian Countries
}

\author{
Luis A. Gil-Alana \\ University of Navarra and University Francisco de Vitoria, Spain
}

Emmanuel Joel Aikins Abakah

The University of Adelaide Business School, Australia.

Moses Kenneth Abakah

Central Securities Depository (GH) Limited, Accra- Ghana

\begin{abstract}
This paper uses fractional integration to explore the stochastic properties of the Financial Stress Indices (FSIs) of ten Asian countries, investigating the bilateral linkages between them to ascertain how financial stress spreads among countries in the region. The results show that all the estimated orders of integration are in the interval $(0,1)$ implying fractional integration and a long memory pattern. Thus, shocks will have transitory though long lasting effects. For the cross-country spillovers of the FSIs, we find that convergence is satisfied in all cases with values of the differencing parameter around 0 and thus showing short memory behaviour. It is worth noting that for the larger economies in the region, Japan and China, financial stress transmission between Japan and the smaller economies was faster than with respect to China. To check for the robustness of the baseline results we also use systemic risk measures for these countries, $\mathrm{CoVaR}$ with the results showing evidence of fractional integration for the individual series, with all values of the differencing parameter in the range $(0,1)$. For convergence, there is a substantial reduction in the degree of integration, though the results are not so clear as with the FSIs.
\end{abstract}

JEL Classification: C22; C51; E44; G10.

Keywords: Financial stress; financial markets; Asian regional area; fractional integration; spillover.

$\begin{array}{ll}\text { Corresponding author: } & \text { Prof. Luis A. Gil-Alana } \\ & \text { University of Navarra } \\ & \text { Faculty of Economics and NCID (ICS) } \\ & \text { Edificio Amigos } \\ & 31009 \text { Pamplona } \\ & \text { Spain }\end{array}$

Email: alana@unav.es

\footnotetext{
* Prof. Luis A. Gil-Alana gratefully acknowledges financial support from the Ministerio de Ciencia, Innovación y Universidades (ECO2017-85503-R). Comments from the Editor and an anonymous reviewer are gratefully acknowledged.
} 


\section{Introduction}

Given the large scale of the financial crises that occurred in Latin America in 1982 and in Asia from 1997-98 which dried up capital flows for a substantial period of time, coupled with the global financial crisis in 2008, the question of how strong financial stress is (FS) and how rapid its transmission is across countries has attracted a great deal of interest among researchers (Chui, Hall, \& Taylor, 2004; Fratzscher, 2003; Kaminsky \& Reinhart, 2003; Salgado, Ricci, \& Caramazza, 2000; Zhang, Yan, \& Tsopanakis, 2018). For instance, the Asian financial crisis that destabilized the Asian economy and then the world economy at the end of the 1990s began in Thailand and then quickly spread to neighbouring economies. After examinng the causes of the Asian economic, currency and financial crisis of 1997-98 and following the impacts of the crisis, the emerging Asian economies over the last decade have been liberalizing their financial sectors by opening up to foreign competition as a measure to curtail future turmoil in the region. Through the help of the International Monetary Fund (IMF), the entire region underwent a series of restructuring and institutional reforms after the financial crisis that led to IMF defining countries such as India, China, Malaysia, Singapore, Indonesia, Philippines and South Korea as 'Emerging Asia'. Through structural adjustments and IMF supported programs, many of the countries affected by the Asian Financial Crisis showed signs of recovery by 1999 with GDP growth resuming. Many of the countries saw their stock markets and currency valuations dramatically reduced from pre-1997 levels, but the solutions imposed set the stage for the reemergence of Asia as a strong investment destination.

Conversely, in responding to the crisis, central banks in the region in past years have implemented a set of conventional and unconventional monetary policies with the objective of promoting monetary stability and soundness in the financial sector to ameliorate the effects of instability within the financial sector and the overall economy. Interestingly, even though the majority of countries in the entire region have implemented adequate prudential regulations 
leading to an improvement in the Asian financial and economic conditions in comparison to recent decades, the overall outlook for financial stability in the region has remained very challenging. One of the biggest challenges has been attributed to negative transmission between the financial sector, securities market stresses and the vulnerability of public finance and economic growth. Clearly, gaining an understanding of financial stress transmission across countries is essential because it can point out efficient pathways towards financial recovery in addition to providing a better understanding of a country's financial stress situation. In addition, following the extensive literature that documents that financial markets are integrated globally as a result of increases in deregulation, globalization and advances in information technology (Chen, Firth, \& Rui, 2002; Fratzscher, 2002; Phylaktis \& Ravazzolo, 2002; Caporale, GilAlana, \& Orlando, 2016; Gil-Alana, Carcel, \& Abakah, 2018), investigating the linkages between countries' stress will enable us to better understand and interpret the behaviour of each country's market conditions in an integrated market. For this purpose, the present study investigates financial stress linkages between ten Asian countries to provide a better understanding of how financial distress in each country interacts with other countries.

This study makes a twofold contribution. First, it applies long memory techniques to provide evidence on the stochastic properties (in particular, the degree of persistence) of the financial stress indices. Second, it examines their long-run linkages on a bilateral basis using fractional integration methods which is a methodology widely used in both finance and economics (Cheung \& Lai, 1993; Baillie \& Bollerslev, 1994; Baillie, 1996; Dueker \& Startz, 1998; Caporale \& Gil-Alana, 2002; Gil-Alana, Abakah \& Rojo, 2020). Unlike the majority of earlier studies, this paper adopts a fractional integration framework that is much more general than the standard approaches based on the $\mathrm{I}(0) / \mathrm{I}(1)$ dichotomy since it allows for fractional values of the integration/cointegration parameter and therefore does not impose restrictive assumptions on the dynamic behaviour of the individual series and their linkages. 
The structure of the paper is as follows: Section 2 provides a brief review of the empirical literature on financial stress. Section 3 outlines the methodology used in the paper. Section 4 describes the data and Section 5 the main empirical findings. Section 6 offers some concluding remarks.

\section{Literature Review}

Evidently, since the global financial and economic crisis from 2007 to 2011, studies on financial stress transmission across countries have become a key focus and an expanding area for both academic and regulatory research. At present, there are several studies that provide ample evidence on the transmission of shocks from one country to another and their overall economic effects on specific industries or on the entire economy with varying definitions for financial stress and the estimation of Financial Stress Indices (FSI). On the definition of financial stress, Hansen (2006) explained financial stress as a risk. According to him, it directly relates to the business cycle, macroeconomic uncertainty and monetary policy prevailing in a country after investigating financial stress in Denmark. In another study, Kliesen \& Smith (2010) note financial stress as a multidimensional problem, which involves a number of simultaneous or temporally contiguous exogenous shocks to factors ranging from financial markets to banks. They conclude that in estimating the financial stress of a single country, it is essential to consider all sets of default probabilities for all classes of products or markets. Grimaldi $(2010,2011)$ considers financial stress as the product across different vulnerable markets and shocks. On the other hand, Chau \& Deesomsak (2014) also outline factors such as exchange rate pressure, financial uproar, depreciation and depletion of foreign reserves, decline in capital inflows, withdrawals from merging equity and debut funds, and band lending as signs of financial stress. Illing \& Liu (2006) put forward that financial stress increases with risk, 
expected financial loss and uncertainty. Sandahl, Holmfeldt, Rydén, \& Strömqvist (2011) after examining financial stress in Sweden defined it as a disruption that affects the ability of financial markets to efficiently function as intermediaries between borrowers and lenders.

In recent years, Financial Stress Indices (FSIs) have been adopted to track the periods of impaired financial intermediation, their magnitude and impact on economic activities. Cardarelli, Elekdag, \& Lall (2011) introduced an FSI methodology for advanced economies which Balakrishnan, Danninger, Elekdag, \& Tytell (2011) built upon to create similar indices for emerging markets. The indices gauge developments in a variety of financial markets, encompassing the banking sector, securities, foreign exchange and sovereign debt markets. A substantial number of studies have used varied modification of Cardarelli et al. (2011) and Balakrishnan et al. (2011) approaches to develop financial stress conditions in individual countries. For instance, Stolbov \& Shchepeleva (2016) extended the conventional approach of estimating FSI proposed by Balakrishnan et al. (2011) the patterns and real effects of financial stress in fourteen emerging economies. Cevik, Dibooglu, \& Kenc (2013) also modified the approach of Balakrishnan et al. (2011) to investigate financial stress in the Turkish economy with the discovery that financial stress can predict growth rates of industrial production, foreign trade and gross fixed capital formation. Hakkio \& Keeton (2009) studied episodes of financial stress in the US and also developed a comprehensive financial stress index. A strand of prior studies such as Hatzius, Hooper, Mishkin, Schoenholtz, \& Watson (2010), Hollo, Kremer, \& Lo Duca (2012) and Oet, Eiben, Bianco, Gramlich, \& Ong (2011) also developed financial stress indices using varied market based indicators in real time and high frequency from the foreign exchange markets and banking sector.

On the impacts of financial stress in specific countries, Stolbov \& Shchepeleva (2016) note that financial stress adversely affects economic activities of emerging economies. Cevik, Dibooglu, \& Kutan (2013) find that financial stress in a country plays a pivotal role with respect 
to the dynamics of macroeconomic indicators in a group of countries (Bulgaria, the Czech Republic, Hungary, Poland and Russia), while Cevik, Dibooglu, \& Kenc (2016) report a significant impact of financial stress on industrial production in South-east Asian economies (Indonesia, South Korea, Malaysia, the Philippines, and Thailand). Melvin \& Taylor (2009) developed a financial stress index for advanced economies and examined the relationship between financial stress index and carry trade.

There are a limited number of studies that focus on cross-country spillovers of financial stress. Stolbov \& Shchepeleva (2016) using a Bayesian Vector AutoRegressive (VAR) provided evidence of financial stress transmission between fourteen emerging economies. Balakrishnan et al. (2011) documented the transmission of financial stress from advanced economies to emerging economies and that differences between emerging economies in the degree of stress transmission are associated with the strength of financial linkages, generally measured by the stock of foreign liabilities, to advanced economies. Balakrishnan et al. (2011) developed a monthly, market based Financial Stress Index (AE-FSI) for seventeen economies covering about 80 percent of the GDP of advanced economies since 1981, and found that nearly all the advanced economies have experienced exceptionally high stress transmission. Recently, Zhang et al. (2018) using a copular based approach examined the tail dependence between financial stress indices of eleven Euro area countries and documented that larger economies in the Euro area tend to have closer upper tail dependence in terms of positive shocks, while smaller economies tend to have closer lower tail dependence with respect to negative shocks.

On the determinants of financial stress transmission across countries, a strand of prior studies attributes the phenomenon to common factors and country specific factors. The common factors have been linked to global shocks (for example, global shifts in market sentiment or risk aversion) which manifest themselves through herd behaviour in markets, cross-country contagion, and common-lender effects via blanket withdrawal of funds by highly 
exposed financial institutions (Broner, Gelos, \& Reinhart, 2006; Calvo, 2005; Pons-Novell, 2003). The role of such common factors is likely related to the increasing financial integration of the majority of emerging economies in the past decades, in other words, financial globalization. Country-specific linkages that facilitate the transmission of financial stress through trade and financial exposures have become a subject of debate in the literature. In particular, Eichengreen \& Rose (1999), Forbes (2002), Glick \& Rose (1999) underscore the importance of stress trade linkages. Fratzscher (2003), Kaminsky \& Reinhart (2003), Salgado et al. (2000) and Van Rijckeghem \& Weder (2001) emphasize financial channels as well as trade. In another study, Forbes \& Chinn (2004) attribute the main role in the transmission of financial shocks to trade, with bank lending of lesser but increasing importance.

\section{Methodology: Fractional Integration}

The methodology used in this work is based on fractional integration that means that the number of differences required to render a series to be stationary $\mathrm{I}(0)$ is a fractional value. We start this section by defining the concept of integration of order 0 . We say that a covariance stationary process $\left(\mathrm{u}_{\mathrm{t}}, \mathrm{t}=0, \pm 1, \ldots\right)$ is $\mathrm{I}(0)$ (also named short memory) if the infinite sum of its autocovariances is finite. Within this category we include the stationary AutoRegressive Moving Average (ARMA) type of models, which is characterized because the autocorrelation structure decays exponentially fast. On the other hand, a process is I(d) if the d-differences of the process becomes $\mathrm{I}(0)$, i.e., a process $\left\{\mathrm{x}_{\mathrm{t}}, \mathrm{t}=0, \pm 1, \ldots\right\}$ is $\mathrm{I}(\mathrm{d})$ if it can be represented as:

$$
(1-L)^{d} x_{t}=u_{t}, \quad t=0, \pm 1, \ldots
$$

where $\mathrm{L}$ is the lag operator $\left(\mathrm{L}^{\mathrm{k}} \mathrm{x}_{\mathrm{t}}=\mathrm{x}_{\mathrm{t}-\mathrm{k}}\right)$ and $\mathrm{d}$ can be any real number, including thus fractional values.

Note that depending on the value of the differencing parameter $d$ above we can consider different approaches. Thus, if $\mathrm{d}=0, \mathrm{x}_{\mathrm{t}}$ is $\mathrm{I}(0)$ or short memory as opposed to the long memory 
case if $d>0$. Values in the range between 0 and 0.5 are still covariance stationary, while nonstationarity takes place as long as $d$ is equal to or above 0.5 . Finally, mean reversion occurs if $d$ is smaller than 1 , and processes with values of $d$ in the range 0.5 and 1 will have shocks with transitory, though long lasting effects, while if $d$ is equal to 1 or above 1 shocks will never disappear by themselves.

The estimation of $\mathrm{d}$ will be conducted by using the Whittle function, which is an approximation to the likelihood function and very convenient in the context of fractional integration. More specifically, we use a version of the LM tests of Robinson (1994) that uses the Whittle function in the frequency domain (Dahlhaus, 1989). This method is parametric and therefore, it requires specific modelling assumptions on the d-differenced process.

\section{Data}

Our dataset has been obtained from the Asian Regional Integration Center (https://aric.adb.org/database/fsi), the database consists of monthly Financial Stress Indices (FSIs) for ASEAN countries for the period from January 1995 to March 2018. Financial Stress Index (FSI) is a composite index that measures the degree of financial stress in four financial markets namely banks, foreign exchange, equity and bonds. The Asian Regional Integration Center adopted the approach of Park and Mercado Jr (2014) to calculate the FSI for each country, which can be found on their website as indicated above. We also consider two regional FSIs, thus the ASEAN+3 FSI and Developing Asia FSI, which are derived from the FSIs of the member economies. The Asian Regional Integration Center computes the FSI for each country from four major financial sectors (Park \& Mercado Jr, 2014). ASEAN+3 includes the ten members of the Association of Southeast Asian Nations (Brunei Darussalam, Cambodia, Indonesia, Lao People's Democratic Republic, Malaysia, Myanmar, the Philippines, Singapore, Thailand, and Vietnam) plus the People Republic of China, Japan, and Korea. On the other 
hand, the emerging and developing Asian countries according to the IMF are Bangladesh, Bhutan, Brunei Darussalam, Cambodia, China, Fiji, India, Indonesia, Kiribati, Lao P.D.R., Malaysia, Maldives, Marshall Islands, Micronesia, Mongolia, Myanmar, Nepal, Palau, Papua New Guinea, the Philippines, Samoa, Solomon Islands, Sri Lanka, Thailand, Timor-Leste, Tonga, Tuvalu, Vanuatu, and Vietnam. (See Table 1 for the list of countries and sample sizes examined in this work).

\section{[Table 1 about here]}

Plots of the monthly FSI for each country are presented in Figure 1. It can be seen that there are stretches of time where the volatility is relatively high and certain periods of time where the volatility is relatively low which clearly suggests an apparent volatility clustering during some periods. We find similar outcomes for the two regional indices. Figure 2 displays the FSI series for the group of countries under examination.

[Figure 1 \& Figure 2 about here]

\section{Empirical Results}

First of all we are interested in the estimation of $d$ in each of the FSI series, and for this purpose we first consider the following regression model,

$$
y_{t}=\alpha+\beta t+x_{t},
$$

where $\alpha$ and $\beta$ are unknown coefficients referring respectively to an intercept and a linear time trend, and $\mathrm{x}_{\mathrm{t}}$ is defined as in equation (1), i.e., following an $\mathrm{I}(\mathrm{d})$ process.

Across Tables 2 and 4 we display the Whittle estimates of $d$ in the model given by (1) and (2), i.e.,

$$
y_{t}=\alpha+\beta t+x_{t}, \quad(1-L)^{d} x_{t}=u_{t}, \quad t=1,2, \ldots,
$$

for three set-ups, corresponding to the cases of no deterministic terms ( $2^{\text {nd }}$ column), including a constant (in the $3^{\text {rd }}$ column), and with a constant and a linear time trend $\left(4^{\text {rd }}\right.$ column), reporting 
also the $95 \%$ confidence intervals of the values of $d$ where the null hypothesis cannot be rejected using Robinson's (1994) tests.

\section{[Tables 2 and 3 about here]}

Table 2 displays the results for the case where $u_{t}$ in (3) is a white noise process. Thus, no autocorrelation is permitted for the error term. The first thing we observe is that the time trend is required in a number of cases, namely Indonesia, Japan, Taipei, Malaysia and Korea for the individual countries, and Developing Asia in case of the Regional FSI indices. For the remaining cases, an intercept seems to be sufficient. Focussing now on the values of $d$ we notice that all the estimated values of $d$ are in the interval $(0,1)$ implying fractional integration and a long memory pattern. For the individual countries, China displays the lowest degree of integration (with an estimated value of $d$ equal to 0.30 , and the interval showing values below 0.5 which means covariance stationarity); at the other extreme Hong Kong presents the highest value (with $d$ equal to 0.70 and the interval being strictly higher than 0.5 and thus being in the nonstationary region); for all the other countries, and also for the two regional indices, the values are about 0.5 , that is, on the borderline between stationary and nonstationary behaviour but in all cases displaying mean reversion, with shocks having transitory though long lasting effects. Table 3 displays the estimated coefficients for each case. We observe a positive time trend coefficient in case of Indonesia, while a negative one is observed in the cases of Japan, Taipei, Singapore, Malaysia and Korea and Developing Asia.

\section{[Tables 4 and 5 about here]}

Tables 4 and 5 reproduce the results in Tables 2 and 3 but allowing for autocorrelation in $u_{t}$ in (3). Here, instead of imposing a specific ARMA model we use a non-parametric approach originally developed by Bloomfield (1973). This method is non-parametric in the sense that no specific functional form exists since the model is only defined in terms of the spectral density function, being this a function very similar to the one produced by ARMA 
models, with autocorrelations decaying exponentially fast but being stationary for all its values unlike what happens in the ARMA models. Using this approach, the time trend is now required only for Taipei and Malaysia (in both cases with a negative coefficient, Table 5) and the estimated values of $d$ are now generally higher than in the previous case of white noise errors. The values range now between 0.18 (Taipei) and 0.81 (Hong Kong) for the individual countries, and for the regional indices the values are 0.79 and 0.89 respectively for ASEAN+3 and Developing Asia. Looking at the confidence bands, we see that for Taipei, the $\mathrm{I}(0)$ null hypothesis cannot be rejected since the value 0 belongs to the $95 \%$ confidence interval; on the other hand, for Hong Kong we cannot reject the null of a unit root since the value 1 belongs now to the corresponding interval. In the remaining cases, the values range between 0 and 1 displaying fractionally integrated mean reverting behaviour.

\section{[Tables 6 and 7 about here]}

In the next set of analysis, reported in Table 6 and Table 7, we study cross-country spillovers of the FSIs, and we consider first the two largest economies in the Asian area as the base countries, studying how financial stress is transmitted from the largest economies in the region to the smaller economies. Table 6 reports financial stress convergence between the countries under examination, thus Indonesia, Hong Kong, India, Japan, Taipei, Singapore, the Philippines, Malaysia and Korea against China. We observe that under no autocorrelation all the confidence intervals include the value of 0 implying evidence of convergence and short memory behaviour. If $\mathrm{u}_{\mathrm{t}}$ is autocorrelated, the values are even smaller and evidence of antipersistence (i.e., $\mathrm{d}<0$ ) is found in the case of Indonesia. Thus, it seems that there is a large degree of convergence in these countries with respect to China. Similar evidence is found when conducting the analysis with respect to Japan (Table 7). In fact, the estimates of d are now even smaller, and evidence of significant negative values of $d$ are found in the cases of China and Hong Kong with no autocorrelation and in the case of Korea with autocorrelated disturbances. 


\section{[Tables 8 and 9 about here]}

Park and Mercado Jr (2014) found that not only the FSIs of advanced economies, but also regional and non-regional emerging market FSIs significantly increase domestic financial stress. Hence, we also looked at the hypothesis of convergence by looking at each individual country in relation to the two regional FSIs, ASEAN+3 and Developing Asia. For this purpose, we conduct the same type of analysis as before but now dividing each series first against ASEAN-3 (Table 8) and then against Developing Asia (Table 9) using both uncorrelated and autocorrelated errors for each of the two scenarios. Looking at the results against ASEAN+3, evidence of $\mathrm{I}(0)$ behaviour is found in all cases independently of imposing autocorrelation or not in the error term, and the same happens in Table 9 with the results with respect to Developing Asia.

\section{[Table 10 about here]}

Table 10 summarizes the results in terms of the estimates of $d$ under the two assumptions for the error term. The lower the value of $d$ is the faster the convergence process is. We compare the d value of each individual country against China, Japan, ASEAN+3 and Developing Asia to ascertain the rate at which convergence occurs. We observe that in the case of no autocorrelation, stress transmission is faster for the following cases: Korea and Japan (0.27), China and Japan (-0.14), Hong Kong and Japan (-0.12), Indonesia and China (-0.09), Singapore and Developing Asia (-0.08), Malaysia and China (-0.07), Japan and Developing Asia (-0.06), the Philippines and China (-0.03) and India and China (-0.02), though only for the first two cases do we obtain evidence of anti-persistence $(d<0)$ at the $5 \%$ level. Under the assumption of autocorrelation, we obtain similar results for the majority of the cases and evidence of anti-persistence is now found in the cases of Indonesia with respect to China (0.32 ) and Korea versus Japan (-0.17). The above results documenting the presence of financial stress transmission indicate that the real sector economy of the individual countries can be 
adversely affected due to the transmission of systematic risks across countries. From the economic standpoint, these results call for policy makers in the region to be vigilant and to go beyond the usual policy prescriptions such as aggregate demand management often employed to ensure price stability. More importantly, policy makers need to be watchful to ensure they are able to determine the source of the financial stress. For example, if the stress transmission is detected to be fuelled by the banking sector, then specific policy actions could be developed and implemented for the banking sector.

To check for the robustness of the baseline results we use systemic risk measures for these countries, CoVaR. The results are displayed in the Appendix. Thus, Tables A1 and A2 refer to the estimates of $\mathrm{d}$ on the individual series based on uncorrelated and autocorrelated errors respectively. Starting with the case of white noise errors, the results re very similar to those in Table 2, with all values of the differencing parameter in the interval $(0,1)$. The highest values correspond to Hong Kong and Philippines along with ASEAN+3 and Developing Asia. The lowest degrees of persistence correspond to Indonesia, China and Malaysia. Allowing for autocorrelation (Table A2) the same evidence of fractional integration is found with the values of $\mathrm{d}$ also in the interval $(0,1)$. Tables A3-A6 reports the results of convergence. Starting with the case of China (Table A3) we observe that generally there is a reduction in the order of integration of the series, suggesting some degree of convergence, and the evidence of $\mathrm{I}(0)$ or short memory behaviour only takes place for Indonesia, India and Malaysia, which are also the countries with the lowest values of $d$ in Table 6 . For ASEAN+3, evidence of $\mathrm{I}(0)$ is found for China, Japan and Malaysia, and finally for Developing Asia, the I(0) hypothesis cannot be rejected for India, Japan and Singapore. Thus, though the $\mathrm{I}(0)$ hypothesis is rejected in a number of cases, generally there is a reduction in the degree of integration compared with the individual series, supporting the hypothesis of convergence in all cases. 


\section{Conclusions}

This paper investigates the stochastic properties of the Financial Stress Index (FSI) of ten Asian countries using fractional integration and monthly FSI data for the period from January 1995 to March 2018. In addition to the above objective, we explore financial stress transmission to ascertain whether there exists financial stress transmission across countries in the region. On the stochastic properties of the FSI for each country, our results indicate that all the estimated values of $\mathrm{d}$ are within the interval $(0,1)$ which indicates evidence of fractional integration and a long memory pattern. China and Taipei display the lowest degrees of integration respectively for white noise and autocorrelated errors, while Hong Kong presents the highest level of integration under the two scenarios. On cross-country spillovers of financial stress across countries in the Asian region, we find evidence of convergence between the larger economies in the region and the smaller economies since the estimated values of $\mathrm{d}$ seem to be about zero in all cases. On the convergence of financial stress across the two regional FSIs, ASEAN+3 and Developing Asia, we find strong evidence of convergence between the individual country's FSI and the regional FSIs. These results imply that the Asian regional area is not a unified policy making area, hence the need for countries to follow divergent policies aimed at taming the effects of financial instability across countries in the region. As it stands, it is clear that financial instability from one country can be transmitted quickly to other countries in the region just as happened in the 1990s, leading to the Asian financial crisis even though past decades saw most countries in the region strengthening the financial system in their respective countries. From these results, it seems that policy makers will have to enact policies to strengthen the financial conditions of the region to prevent the occurrence of further transmission of financial instability across countries in the region. 


\section{References}

Baillie, R. T. (1996). Long memory processes and fractional integration in econometrics. Journal of Econometrics, 73(1), 5-59.

Baillie, R. T., \& Bollerslev, T. (1994). Cointegration, fractional cointegration, and exchange rate dynamics. The Journal of Finance, 49(2), 737-745.

Balakrishnan, R., Danninger, S., Elekdag, S., \& Tytell, I. (2011). The transmission of financial stress from advanced to emerging economies. Emerging Markets Finance and Trade, 47(sup2), 40-68.

Bloomfield, P. (1973). An exponential model in the spectrum of a scalar time series. Biometrika, 60, 217-226.

Broner, F. A., Gelos, R. G., \& Reinhart, C. M. (2006). When in peril, retrench: Testing the portfolio channel of contagion. Journal of International Economics, 69(1), 203-230.

Calvo, G. A. (2005). Emerging capital markets in turmoil: bad luck or bad policy? MIT Press Books, 1 .

Caporale, G. M., \& Gil-Alana, L. A. (2002). Fractional integration and mean reversion in stock prices. The Quarterly Review of Economics and Finance, 42(3), 599-609.

Caporale, G. M., Gil-Alana, L. A., \& Orlando, J. C. (2016). Linkages between the US and European stock markets: a fractional cointegration approach. International Journal of Finance \& Economics, 21(2), 143-153.

Cardarelli, R., Elekdag, S., \& Lall, S. (2011). Financial stress and economic contractions. Journal of Financial Stability, 7(2), 78-97.

Cevik, E. I., Dibooglu, S., \& Kenc, T. (2013). Measuring financial stress in Turkey. Journal of Policy Modeling, 35(2), 370-383.

Cevik, E. I., Dibooglu, S., \& Kenc, T. (2016). Financial stress and economic activity in some emerging Asian economies. Research in International Business and Finance, 36, $127-$ 139.

Cevik, E. I., Dibooglu, S., \& Kutan, A. M. (2013). Measuring financial stress in transition economies. Journal of Financial Stability, 9(4), 597-611.

Chau, F., \& Deesomsak, R. (2014). Does linkage fuel the fire? The transmission of financial stress across the markets. International Review of Financial Analysis, 36, 57-70.

Chen, G.-m., Firth, M., \& Rui, O. M. (2002). Stock market linkages: evidence from Latin America. Journal of Banking \& Finance, 26(6), 1113-1141.

Cheung, Y.-W., \& Lai, K. S. (1993). A fractional cointegration analysis of purchasing power parity. Journal of Business \& Economic Statistics, 11(1), 103-112. 
Chui, M. K., Hall, S., \& Taylor, A. (2004). Crisis spillovers in emerging market economies: interlinkages, vulnerabilities and investor behaviour. Working Paper 212, The Bank of England, 2004, pp. 1-44

Dahlhaus, R. (1989) Efficient parameter estimation for self-similar process, Annals of Statistics, 17, 1749-1766.

Dueker, M., \& Startz, R. (1998). Maximum-likelihood estimation of fractional cointegration with an application to US and Canadian bond rates. Review of Economics and Statistics, $80(3), 420-426$.

Eichengreen, B., \& Rose, A. K. (1999). Contagious currency crises: Channels of conveyance. In Changes in exchange rates in rapidly developing countries: Theory, practice, and policy issues (NBER-EASE volume 7) (pp. 29-56): University of Chicago Press.

Forbes, K. J. (2002). Are trade linkages important determinants of country vulnerability to crises? In Preventing currency crises in emerging markets (pp. 77-132): University of Chicago Press.

Forbes, K. J., \& Chinn, M. D. (2004). A decomposition of global linkages in financial markets over time. Review of Economics and Statistics, 86(3), 705-722.

Fratzscher, M. (2002). Financial market integration in Europe: on the effects of EMU on stock markets. International Journal of Finance \& Economics, 7(3), 165-193.

Fratzscher, M. (2003). On currency crises and contagion. International Journal of Finance \& Economics, 8(2), 109-129.

Gil-Alana, L., Abakah, E. J. A, \& Rojo, M.F.. (2019). Cryptocurrencies and stock markets indices. Are they related?. Research in International Business and Finance (forthcoming). https://doi.org/10.1016/j.ribaf.2019.101063

Gil-Alana, L., Carcel, H., \& Abakah, E. J. A. (2018). On the linkages between Africa's emerging equity markets and global markets: Evidence from fractional integration and cointegration. Review of Development Finance, 8(2), 96-105.

Glick, R., \& Rose, A. K. (1999). Contagion and trade: why are currency crises regional? Journal of International Money and Finance, 18(4), 603-617.

Grimaldi, M. (2010). Detecting and interpreting financial stress in the euro area. ECB Working Paper Series No. 1214, www.ecb.europa.eu/pub/pdf/scpwps/ecbwp1214.pdf.

Grimaldi, M. (2011). Up for count? Central bank words and financial stress. Central Bank Words and Financial Stress (April 2011). Riksbank Research Paper Series(83).

Hakkio, C. S., \& Keeton, W. R. (2009). Financial stress: what is it, how can it be measured, and why does it matter? Economic Review, 94(2), 5-50. 
Hansen, J. L. (2006). A risk index for Euro-denominated assets. National Bank of Denmark Working Paper No. 36/2006.

Hatzius, J., Hooper, P., Mishkin, F. S., Schoenholtz, K. L., \& Watson, M. W. (2010). Financial conditions indexes: A fresh look after the financial crisis (No. w16150). National Bureau of Economic Research

Hollo, D., Kremer, M., \& Lo Duca, M. (2012). CISS-a composite indicator of systemic stress in the financial system. ECB Working Paper No.1426.

Illing, M., \& Liu, Y. (2006). Measuring financial stress in a developed country: An application to Canada. Journal of Financial Stability, 2(3), 243-265.

Kaminsky, G. L., \& Reinhart, C. (2003). The center and the periphery: the globalization of financial turmoil (No. w9479). National Bureau of Economic Research.

Kliesen, K. L., \& Smith, D. C. (2010). Measuring financial market stress. Federal Reserve Bank of St. Louis National Economic Trends; http://research.stlouisfed.org/publications/net/20100101/cover.pdf.

Melvin, M., \& Taylor, M. P. (2009). The crisis in the foreign exchange market. Journal of International Money and Finance, 28(8), 1317-1330.

Oet, M. V., Eiben, R., Bianco, T., Gramlich, D., \& Ong, S. J. (2011). Financial stress index: Identification of systemic risk conditions. Paper presented at the 24th Australasian Finance and Banking Conference.

Park, C.-Y., \& Mercado Jr, R. V. (2014). Determinants of financial stress in emerging market economies. Journal of Banking \& Finance, 45, 199-224.

Phylaktis, K., \& Ravazzolo, F. (2002). Measuring financial and economic integration with equity prices in emerging markets. Journal of International Money and Finance, 21(6), 879-903.

Pons-Novell, J. (2003). Strategic bias, herding behaviour and economic forecasts. Journal of Forecasting, 22(1), 67-77.

Robinson, P.M. (1994). Efficient tests of nonstationary hypotheses, Journal of the American Statistical Association 89, 428, 1420-1437.

Salgado, M. R., Ricci, M. L. A., \& Caramazza, M. F. (2000). Trade and financial contagion in currency crises: International Monetary Fund.

Sandahl, J. F., Holmfeldt, M., Rydén, A., \& Strömqvist, M. (2011). An index of financial stress for Sweden. Sveriges Riksbank Economic Review, 2, 49-67.

Stolbov, M., \& Shchepeleva, M. (2016). Financial stress in emerging markets: Patterns, real effects, and cross-country spillovers. Review of Development Finance, 6(1), 71-81.

Van Rijckeghem, C., \& Weder, B. (2001). Sources of contagion: is it finance or trade? Journal of International Economics, 54(2), 293-308. 
Zhang, D., Yan, M., \& Tsopanakis, A. (2018). Financial stress relationships among Euro area countries: an R-vine copula approach. The European Journal of Finance, 24(17), 15871608. 
Figure 1: Time series plots
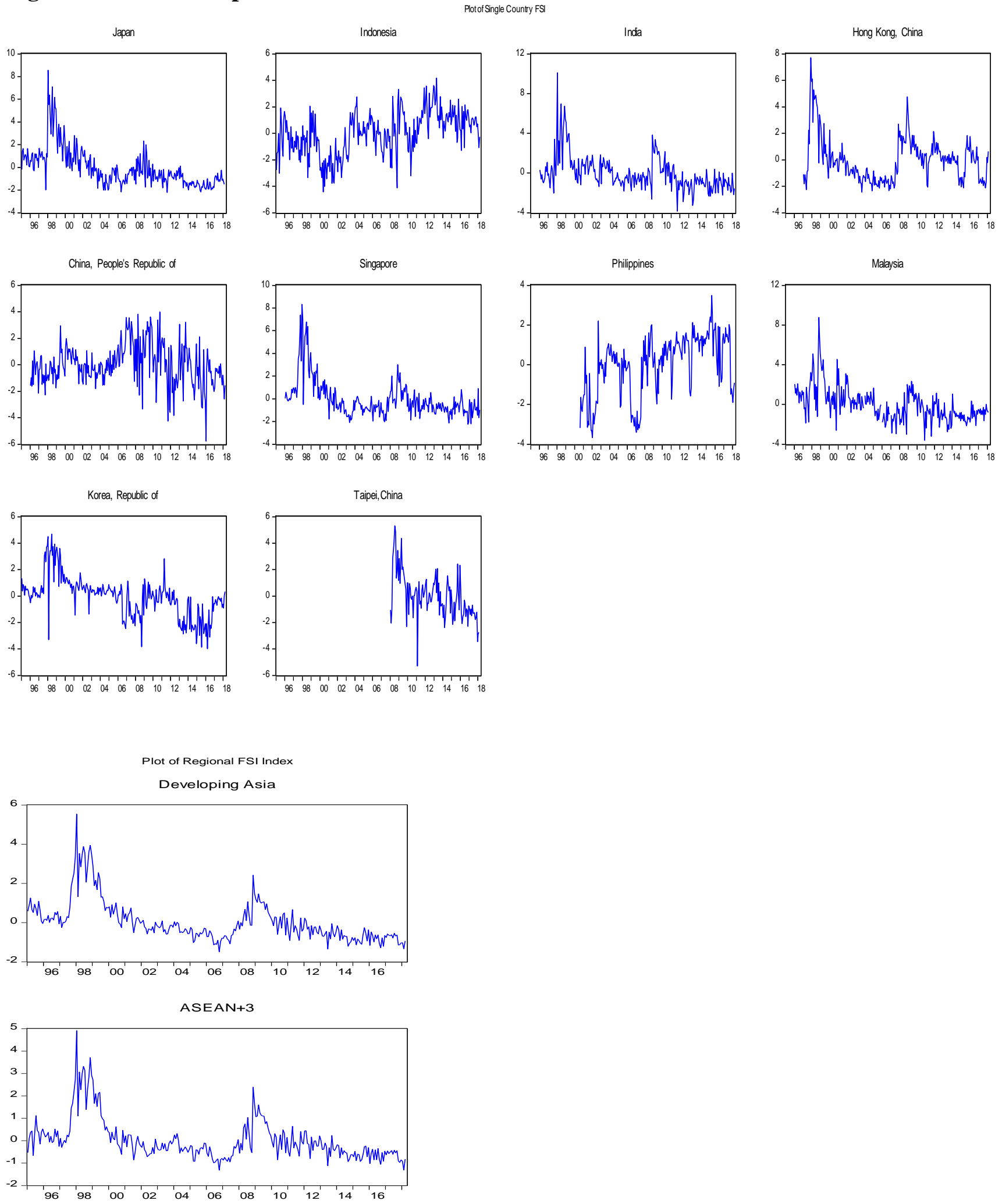
Figure 2: FSI series

FSI Index

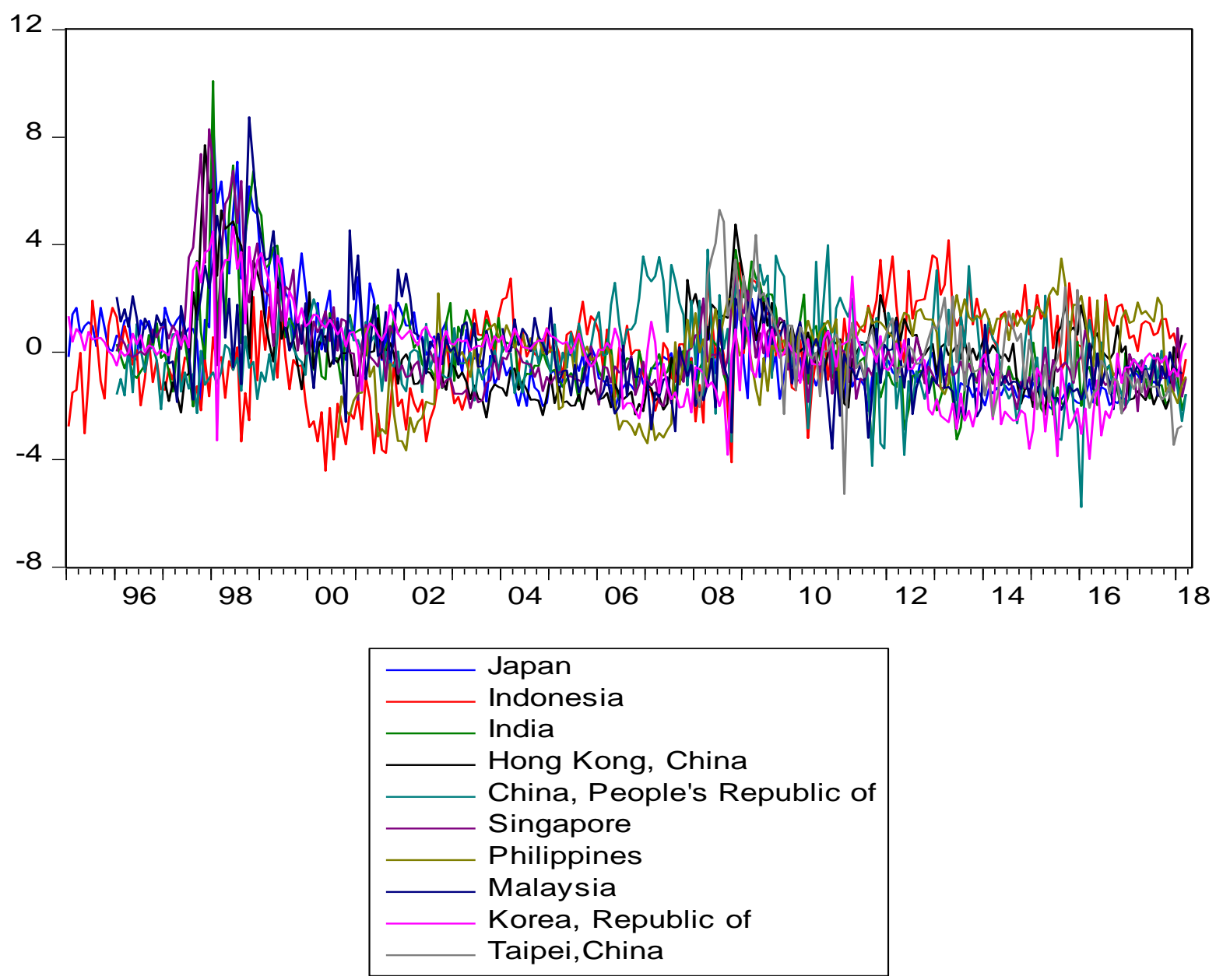


Table 1: Data and sample sizes

\begin{tabular}{lccc}
\hline Series & Starting Date & Ending Date & N. Of \\
\hline Single Country FSI & & & \\
\hline Indonesia & 1995 M1 & 2018 M3 & 279 \\
China & 1996 M1 & 2018 M3 & 267 \\
Hong Kong & 1997 M1 & 2018 M2 & 254 \\
India & 1996 M1 & 2018 M3 & 267 \\
Japan & 1995 M1 & 2018 M2 & 278 \\
Taipei & 2008 M1 & 2018 M2 & 122 \\
Singapore & 1996 M1 & 2018 M3 & 267 \\
Philippines & 2000 M8 & 2018 M3 & 212 \\
Malaysia & 1996 M1 & 2018 M2 & 266 \\
Korea & 1995 M1 & 2018 M3 & 279 \\
\hline Regional FSI Index & & & 279 \\
\hline Asean-3 & 1995 M1 & 2018 M3 & 279 \\
Developing Asia & 1995 M1 & 2018 M3 & \\
\hline
\end{tabular}


Table 2: Estimates of $\mathrm{d}$ (and $95 \%$ confidence bands) based on white noise errors

\begin{tabular}{|c|c|c|c|}
\hline Series & No terms & An intercept & A linear time trend \\
\hline \multicolumn{4}{|c|}{ Single Country FSI } \\
\hline Indonesia & $0.42(0.36,0.49)$ & $0.41 \quad(0.35,0.48)$ & $0.39 \quad(0.32,0.47)$ \\
\hline China & $0.30 \quad(0.24,0.38)$ & $0.30 \quad(0.24,0.38)$ & $0.30 \quad(0.24,0.37)$ \\
\hline Hong Kong & $0.69 \quad(0.61,0.78)$ & $0.70 \quad(0.62,0.79)$ & $0.70 \quad(0.62,0.79)$ \\
\hline India & $0.45 \quad(0.39,0.52)$ & $0.44 \quad(0.38,0.52)$ & $0.43 \quad(0.36,0.51)$ \\
\hline Japan & $0.49 \quad(0.44,0.56)$ & $0.49(0.43,0.55)$ & $0.46 \quad(0.39,0.54)$ \\
\hline Taipei & $0.44 \quad(0.34,0.58)$ & $0.44(0.33,0.58)$ & $0.37 \quad(0.23,0.56)$ \\
\hline Singapore & $0.53(0.47,0.60)$ & $0.52(0.46,0.59)$ & $0.51 \quad(0.45,0.59)$ \\
\hline Philippines & $0.60 \quad(0.52,0.69)$ & $0.57 \quad(0.49,0.67)$ & $0.57 \quad(0.49,0.68)$ \\
\hline Malaysia & $0.44 \quad(0.37,0.52)$ & $0.42(0.36,0.51)$ & $0.40 \quad(0.32,0.50)$ \\
\hline Korea & $0.46 \quad(0.41,0.53)$ & $0.46 \quad(0.41,0.52)$ & $0.43 \quad(0.36,0.50)$ \\
\hline \multicolumn{4}{|c|}{ Regional FSI Index } \\
\hline Asean-3 & $0.58 \quad(0.53,0.65)$ & $0.58 \quad(0.53,0.65)$ & $0.57 \quad(0.52,0.65)$ \\
\hline Developing Asia & $0.62(0.57,0.68)$ & $0.61 \quad(0.56,0.67)$ & $0.60(0.54,0.67)$ \\
\hline
\end{tabular}

The values in parenthesis are the $95 \%$ confidence intervals of the non-rejection values of $\mathrm{d}$ using Robinson (1994). In both, the most appropriate model according to the deterministic terms. 
Table 3: Estimated coefficients for the selected models in Table 2

\begin{tabular}{|c|c|c|c|c|c|c|}
\hline Series & d & & Intercept & & Time trenc & \\
\hline \multicolumn{7}{|c|}{ Single Country FSI } \\
\hline Indonesia & 0.39 & $(0.32,0.47)$ & -1.2929 & $(-2.13)$ & 0.0085 & $(2.20)$ \\
\hline China & 0.30 & $(0.24,0.38)$ & -0.2208 & $(-2.59)$ & --- & \\
\hline Hong Kong & 0.70 & $(0.62,0.79)$ & -0.7008 & $(-1.87)$ & --- & \\
\hline India & 0.44 & $(0.38,0.52)$ & 0.1247 & $(2.21)$ & --- & \\
\hline Japan & 0.46 & $(0.39,0.54)$ & 1.1249 & $(1.88)$ & -0.0099 & $(-2.37)$ \\
\hline Taipei & 0.37 & $(0.23,0.56)$ & 1.1853 & $(1.69)$ & -0.0237 & $(-2.38)$ \\
\hline Singapore & 0.52 & $(0.46,0.59)$ & 0.3836 & $(1.71)$ & & \\
\hline Philippines & 0.57 & $(0.49,0.67)$ & -1.7916 & $(-2.66)$ & & \\
\hline Malaysia & 0.40 & $(0.32,0.50)$ & 1.5575 & $(2.47)$ & -0.0109 & $(-2.56)$ \\
\hline Korea & 0.43 & $(0.36,0.50)$ & 1.1048 & $(2.04)$ & -0.0087 & $(-2.41)$ \\
\hline \multicolumn{7}{|c|}{ Regional FSI Index } \\
\hline Asean-3 & 0.58 & $(0.53,0.65)$ & -0.0505 & $(-3.14)$ & --- & \\
\hline Developing Asia & 0.60 & $(0.54,0.67)$ & 0.7834 & $(1.99)$ & -0.0063 & $(-1.64)$ \\
\hline
\end{tabular}

In parenthesis, the 95\% confidence band of the non-rejection values of d using Robinson (1994) (in column 2); t-values (in columns 3 and 4) 
Table 4: Estimates of $d$ (and $95 \%$ confidence bands) based on autocorrelation

\begin{tabular}{|c|c|c|c|}
\hline Series & No terms & An intercept & A linear time \\
\hline \multicolumn{4}{|c|}{ Single Country FSI } \\
\hline Indonesia & $0.52(0.43,0.66)$ & $0.51 \quad(0.40,0.65)$ & $0.49 \quad(0.35,0.65)$ \\
\hline China & $0.41 \quad(0.30,0.54)$ & $0.41 \quad(0.30,0.53)$ & $0.41 \quad(0.30,0.53)$ \\
\hline Hong Kong & $0.77 \quad(0.61,0.98)$ & $0.81(0.63,1.02)$ & $0.81 \quad(0.63,1.02)$ \\
\hline India & $0.49(0.40,0.62)$ & $0.50 \quad(0.39,0.62)$ & $0.47 \quad(0.34,0.60)$ \\
\hline Japan & $0.38 \quad(0.20,0.71)$ & $0.57 \quad(0.49,0.69)$ & $0.55 \quad(0.40,0.70)$ \\
\hline Taipei & $0.66(0.55,0.67)$ & $0.37 \quad(0.21,0.70)$ & $0.18(-0.06,0.67)$ \\
\hline Singapore & $0.72(0.55,0.82)$ & $0.66(0.54,0.81)$ & $0.65 \quad(0.52,0.81)$ \\
\hline Philippines & $0.48 \quad(0.37,0.93)$ & $0.62(0.48,0.88)$ & $0.63(0.45,0.86)$ \\
\hline Malaysia & $0.60(0.50,0.63)$ & $0.46(0.36,0.61)$ & $0.39 \quad(0.25,0.60)$ \\
\hline Korea & $0.46(0.41,0.72)$ & $0.58 \quad(0.49,0.70)$ & $0.55 \quad(0.42,0.70)$ \\
\hline \multicolumn{4}{|c|}{ Regional FSI Index } \\
\hline Asean-3 & $0.79(0.68,0.93)$ & $0.79(0.68,0.94)$ & $0.80 \quad(0.68,0.94)$ \\
\hline Developing Asia & $0.85 \quad(0.73,0.98)$ & $0.89 \quad(0.72,0.99)$ & $0.84 \quad(0.72,0.99)$ \\
\hline
\end{tabular}

The values in parenthesis are the $95 \%$ confidence intervals of the non-rejection values of $d$ using Robinson (1994). In both, the most appropriate model according to the deterministic terms. 
Table 5: Estimated coefficients for the selected models in Table 4

\begin{tabular}{|c|c|c|c|c|}
\hline Series & d & & Intercept & Time trend \\
\hline \multicolumn{5}{|c|}{ Single Country FSI } \\
\hline Indonesia & 0.51 & $(0.40,0.65)$ & $-1.4613 \quad(-1.87)$ & ----- \\
\hline China & 0.41 & $(0.30,0.53)$ & $-0.3752 \quad(-2.50)$ & ----- \\
\hline Hong Kong & 0.81 & $(0.63,1.02)$ & $-0.9543(-1.90)$ & ----- \\
\hline India & 0.50 & $(0.39,0.62)$ & $0.6569 \quad(2.81)$ & ----- \\
\hline Japan & 0.57 & $(0.49,0.69)$ & $0.7945 \quad(1.80)$ & ----- \\
\hline Taipei & 0.18 & $(-0.06,0.67)$ & $1.5632 \quad(3.62)$ & $-0.0262 \quad(-4.47)$ \\
\hline Singapore & 0.66 & $(0.54,0.81)$ & $0.4535 \quad(1.73)$ & ----- \\
\hline Philippines & 0.62 & $(0.48,0.88)$ & $-2.4050 \quad(-3.05)$ & ----- \\
\hline Malaysia & 0.39 & $(0.25,0.60)$ & $1.5554 \quad(2.51)$ & $-0.0109 \quad(-2.64)$ \\
\hline Korea & 0.58 & $(0.49,0.70)$ & 1.0355 (1.64) & ----- \\
\hline \multicolumn{5}{|c|}{ Regional FSI Index } \\
\hline Asean-3 & 0.79 & $(0.68,0.94)$ & $-0.3286 \quad(-2.74)$ & ----- \\
\hline Developing Asia & 0.89 & $(0.72,0.99)$ & $0.6451 \quad(1.98)$ & ----- \\
\hline
\end{tabular}

In parenthesis, the $95 \%$ confidence band of the non-rejection values of d using Robinson (1994) (in column 2); t-values (in columns 3 and 4) 
Table 6: Estimates of $d$ in the convergence against CHINA

\begin{tabular}{|c|c|c|c|}
\hline Series & No terms & An intercept & A linear time trend \\
\hline \multicolumn{4}{|c|}{ i) No autocorrelation } \\
\hline Indonesia & $-0.09(-0.19,0.05)$ & $-0.09(-0.20,0.05)$ & $-0.09(-0.20,0.05)$ \\
\hline Hong Kong & $-0.02(-0.11,0.09)$ & $-0.02(-0.11,0.09)$ & $-0.02(-0.12,0.08)$ \\
\hline India & $-0.02(-0.11,0.09)$ & $-0.02(-0.11,0.09)$ & $-0.03(-0.12,0.09)$ \\
\hline Japan & $-0.02(-0.10,0.08)$ & $-0.02(-0.10,0.08)$ & $-0.02(-0.10,0.08)$ \\
\hline Taipei & $-0.02(-0.13,0.14)$ & $-0.02(-0.12,0.13)$ & $-0.03(-0.14,0.13)$ \\
\hline Singapore & $-0.01(-0.09,0.10)$ & $-0.01(-0.09,0.10)$ & $-0.01(-0.09,0.10)$ \\
\hline Philippines & $-0.03(-0.12,0.09)$ & $-0.03(-0.12,0.09)$ & $-0.03(-0.12,0.09)$ \\
\hline Malaysia & $-0.07(-0.17,0.06)$ & $-0.07(-0.17,0.06)$ & $-0.07(-0.17,0.06)$ \\
\hline Korea & $0.03(-0.04,0.12)$ & $0.03(-0.04,0.12)$ & $0.01(-0.08,0.10)$ \\
\hline \multicolumn{4}{|c|}{ ii) with autocorrelation } \\
\hline Indonesia & $-0.32(-0.53,-0.03)$ & $-0.33(-0.49,-0.03)$ & $-0.34(-0.58,-0.03)$ \\
\hline Hong Kong & $-0.12(-0.26,0.06)$ & $-0.11(-0.24,0.05)$ & $-0.11(-0.24,0.05)$ \\
\hline India & $-0.10(-0.20,0.07)$ & $-0.09(-0.19,0.07)$ & $-0.13(-0.27,0.05)$ \\
\hline Japan & $-0.06(-0.17,0.09)$ & $-0.06(-0.17,0.09)$ & $-0.07(-0.18,0.09)$ \\
\hline Taipei & $-0.12\left(\begin{array}{ll}-0.38, & 0.13)\end{array}\right.$ & $-0.13(-0.28,0.11)$ & $-0.13(-0.30,0.10)$ \\
\hline Singapore & $-0.07(-0.10,0.10)$ & $-0.07(-0.10,0.10)$ & $-0.09(-0.08,0.08)$ \\
\hline Philippines & $-0.11(-0.29,0.15)$ & $-0.11\left(\begin{array}{lll}-0.29, & 0.15)\end{array}\right.$ & $-0.11 \quad(-0.29,0.15)$ \\
\hline Malaysia & $-0.21(-0.37,0.02)$ & $-0.20(-0.38,0.02)$ & $\begin{array}{lll}-0.21 & (-0.40, & 0.02)\end{array}$ \\
\hline Korea & $0.07(-0.04,0.21)$ & $0.06(-0.04,0.20)$ & $0.06(-0.04,0.20)$ \\
\hline
\end{tabular}

The values in parenthesis are the $95 \%$ confidence intervals of the non-rejection values of $\mathrm{d}$ using Robinson (1994). In both, the most appropriate model according to the deterministic terms. 
Table 7: Estimates of $d$ in the convergence against JAPAN

\begin{tabular}{|c|c|c|c|}
\hline Series & No terms & An intercept & A linear time trend \\
\hline \multicolumn{4}{|c|}{ i) No autocorrelation } \\
\hline Indonesia & $0.01(-0.07,0.10)$ & $0.01(-0.07,0.10)$ & $0.00(-0.07,0.10)$ \\
\hline China & $-0.11(-0.17,-0.03)$ & $-0.11(-0.17,-0.03)$ & $-0.14(-0.22,-0.06)$ \\
\hline Hong Kong & $-0.12(-0.17,-0.05)$ & $-0.12(-0.17,-0.05)$ & $-0.11(-0.17,-0.05)$ \\
\hline India & $0.05(-0.02,0.14)$ & $0.05(-0.02,0.14)$ & $0.04(-0.03,0.13)$ \\
\hline Taipei & $-0.06(-0.16,0.10)$ & $-0.06(-0.16,0.10)$ & $-0.08(-0.20,0.08)$ \\
\hline Singapore & $0.01(-0.08,0.12)$ & $0.01(-0.08,0.12)$ & $0.01(-0.08,0.12)$ \\
\hline Philippines & $0.01(-0.05,0.09)$ & $0.01(-0.05,0.09)$ & $0.01(-0.06,0.08)$ \\
\hline Malaysia & $0.00(-0.07,0.10)$ & $0.00(-0.07,0.10)$ & $-0.03(-0.12,0.08)$ \\
\hline Korea & $-0.27(-0.33,0.19)$ & $-0.27(-0.33,0.19)$ & $-0.27(-0.33,0.19)$ \\
\hline \multicolumn{4}{|c|}{ ii) with autocorrelation } \\
\hline Indonesia & $-0.03(-0.13,0.14)$ & $-0.03(-0.13,0.14)$ & $-0.04(-0.17,0.13)$ \\
\hline China & $-0.03(-0.14,0.12)$ & $-0.03(-0.14,0.11)$ & $-0.11(-0.23,0.05)$ \\
\hline Hong Kong & $0.09(-0.03,0.25)$ & $0.09(-0.03,0.25)$ & $0.08(-0.04,0.25)$ \\
\hline India & $0.06(-0.05,0.22)$ & $0.06(-0.05,0.22)$ & $0.04(-0.07,0.22)$ \\
\hline Taipei & $-0.18(-0.34, \quad 0.02)$ & $-0.18(-0.34,0.02)$ & $-0.24(-0.40,0.00)$ \\
\hline Singapore & $-0.12(-0.23,0.06)$ & $-0.12(-0.24,0.06)$ & $-0.12(-0.24,0.06)$ \\
\hline Philippines & $0.37 *(0.19, \quad 0.67)$ & $0.37\left(\begin{array}{ll}0.19, & 0.68)\end{array}\right.$ & $0.37\left(\begin{array}{ll}0.19, & 0.68)\end{array}\right.$ \\
\hline Malaysia & $-0.07 \quad(-0.17,0.06)$ & $-0.07(-0.18,0.06)$ & $-0.15(-0.26,0.02)$ \\
\hline Korea & $-0.17(-0.28,-0.04)$ & $-0.17(-0.27,-0.04)$ & $-0.17(-0.28,-0.04)$ \\
\hline
\end{tabular}


Table 8: Estimates of $d$ in the convergence against ASEAN-3

\begin{tabular}{|c|c|c|c|}
\hline Series & No terms & An intercept & A linear time \\
\hline \multicolumn{4}{|c|}{ i) No autocorrelation } \\
\hline Indonesia & $-0.03(-0.11,0.08)$ & $-0.03(-0.11,0.08)$ & $-0.03 \quad(-0.12,0.08)$ \\
\hline China & $-0.02 \quad(-0.09,0.08)$ & $-0.02 \quad(-0.09,0.08)$ & $-0.02 \quad(-0.09,0.08)$ \\
\hline Hong Kong & $0.01(-0.05,0.10)$ & $0.01(-0.05,0.10)$ & $0.01 \quad(-0.06,0.10)$ \\
\hline India & $-0.01 \quad(-0.08,0.09)$ & $-0.01 \quad(-0.09,0.09)$ & $-0.01 \quad(-0.09,0.09)$ \\
\hline Japan & $-0.01 \quad(-0.09,0.08)$ & $-0.01 \quad(-0.09,0.08)$ & $-0.01 \quad(-0.09,0.08)$ \\
\hline Taipei & $0.03 \quad(-0.07,0.16)$ & $0.03 \quad(-0.07,0.16)$ & $0.03 \quad(-0.07,0.16)$ \\
\hline Singapore & $-0.04(-0.13,0.08)$ & $-0.04(-0.13,0.08)$ & $-0.04(-0.13,0.08)$ \\
\hline Philippines & $0.05 \quad(-0.05,0.19)$ & $0.05 \quad(-0.05,0.19)$ & $0.05 \quad(-0.05,0.19)$ \\
\hline Malaysia & $-0.01(-0.09,0.08)$ & $-0.01(-0.09,0.08)$ & $-0.02(-0.09,0.08)$ \\
\hline \multirow[t]{2}{*}{ Korea } & $-0.01(-0.08,0.08)$ & $-0.01(-0.09,0.08)$ & $-0.02(-0.08,0.08)$ \\
\hline & \multicolumn{3}{|c|}{ ii) with autocorrelation } \\
\hline Indonesia & $-0.13(-0.26,0.01)$ & $-0.13 \quad(-0.25,0.01)$ & $-0.14 \quad(-0.27,0.01)$ \\
\hline China & $-0.03 \quad(-0.16,0.14)$ & $-0.03 \quad(-0.16,0.14)$ & $-0.03 \quad(-0.16,0.14)$ \\
\hline Hong Kong & $0.03(-0.06,0.19)$ & $0.03(-0.06,0.19)$ & $0.03(-0.08,0.19)$ \\
\hline India & $-0.03(-0.15,0.12)$ & $-0.03 \quad(-0.13,0.12)$ & $-0.04 \quad(-0.13,0.12)$ \\
\hline Japan & $-0.04(-0.14,0.13)$ & $-0.04 \quad(-0.14,0.13)$ & $-0.04 \quad(-0.15,0.13)$ \\
\hline Taipei & $0.02 \quad(-0.17,0.25)$ & $0.02 \quad(-0.17,0.25)$ & $0.02 \quad(-0.15,0.26)$ \\
\hline Singapore & $-0.15(-0.28,0.10)$ & $-0.15(-0.29,0.10)$ & $-0.15(-0.33,0.10)$ \\
\hline Philippines & $-0.12(-0.27,0.07)$ & $-0.12(-0.27,0.07)$ & $-0.12(-0.26,0.08)$ \\
\hline Malaysia & $-0.04(-0.14,0.13)$ & $-0.04(-0.14,0.13)$ & $-0.05(-0.16,0.12)$ \\
\hline Korea & $-0.04(-0.15,0.12)$ & $-0.04(-0.15,0.12)$ & $-0.05(-0.16,0.12)$ \\
\hline
\end{tabular}

The values in parenthesis are the $95 \%$ confidence intervals of the non-rejection values of $\mathrm{d}$ using Robinson (1994). In both, the most appropriate model according to the deterministic terms. 
Table 9: Estimates of $d$ in the convergence against DEVELOPING ASIA

\begin{tabular}{|c|c|c|c|}
\hline Series & No terms & An intercept & A linear time \\
\hline \multicolumn{4}{|c|}{ i) No autocorrelation } \\
\hline Indonesia & $-0.01 \quad(-0.09,0.09)$ & $-0.01 \quad(-0.09,0.09)$ & $-0.02 \quad(-0.10,0.08)$ \\
\hline China & $0.00(-0.07,0.09)$ & $0.00(-0.07,0.09)$ & $0.00(-0.08,0.09)$ \\
\hline Hong Kong & $-0.04(-0.12,0.05)$ & $-0.04(-0.12,0.05)$ & $-0.04(-0.12,0.05)$ \\
\hline India & $0.00 \quad(-0.07,0.09)$ & $0.00 \quad(-0.07,0.09)$ & $0.00 \quad(-0.07,0.09)$ \\
\hline Japan & $-0.04 \quad(-0.10,0.05)$ & $-0.04 \quad(-0.10,0.05)$ & $-0.06 \quad(-0.15,0.03)$ \\
\hline Taipei & $-0.04(-0.16,0.11)$ & $-0.04(-0.14,0.10)$ & $-0.03(-0.14,0.12)$ \\
\hline Singapore & $-0.07(-0.12,0.01)$ & $-0.07(-0.13,0.01)$ & $-0.08(-0.15,0.00)$ \\
\hline Philippines & $-0.01 \quad(-0.10,0.10)$ & $-0.01(-0.10,0.11)$ & $-0.02(-0.08,0.11)$ \\
\hline Malaysia & $-0.01(-0.08,0.08)$ & $-0.01(-0.08,0.08)$ & $-0.01(-0.08,0.08)$ \\
\hline \multirow[t]{2}{*}{ Korea } & $-0.03(-0.11,0.06)$ & $-0.03(-0.11,0.06)$ & $-0.05(-0.13,0.05)$ \\
\hline & \multicolumn{3}{|c|}{ ii) with autocorrelation } \\
\hline Indonesia & $-0.03 \quad(-0.18,0.12)$ & $-0.03 \quad(-0.17,0.12)$ & $-0.06 \quad(-0.19,0.12)$ \\
\hline China & $-0.01 \quad(-0.10,0.18)$ & $-0.01 \quad(-0.10,0.18)$ & $-0.01 \quad(-0.11,0.16)$ \\
\hline Hong Kong & $-0.03(-0.15,0.16)$ & $-0.03(-0.15,0.16)$ & $-0.03(-0.15,0.16)$ \\
\hline India & $0.01 \quad(-0.12,0.18)$ & $0.01 \quad(-0.12,0.17)$ & $0.01 \quad(-0.12,0.18)$ \\
\hline Japan & $-0.01 \quad(-0.12,0.13)$ & $-0.01 \quad(-0.12,0.13)$ & $-0.07 \quad(-0.16,0.08)$ \\
\hline Taipei & $-0.10 \quad(-0.29,0.15)$ & $-0.11 \quad(-0.27,0.15)$ & $0.00 \quad(-0.21,0.45)$ \\
\hline Singapore & $-0.02(-0.12,0.12)$ & $-0.02(-0.11,0.12)$ & $-0.06(-0.15,0.10)$ \\
\hline Philippines & $-0.06(-0.19,0.15)$ & $-0.06(-0.19,0.14)$ & $0.02(-0.15,0.18)$ \\
\hline Malaysia & $0.00(-0.12,0.15)$ & $0.00(-0.12,0.15)$ & $-0.01(-0.11,0.14)$ \\
\hline Korea & $-0.04(-0.16,0.15)$ & $-0.04(-0.16,0.15)$ & $-0.08(-0.21,0.13)$ \\
\hline
\end{tabular}

The values in parenthesis are the $95 \%$ confidence intervals of the non-rejection values of $\mathrm{d}$ using Robinson (1994). In both, the most appropriate model according to the deterministic terms. 
Table 10: Summary results of the convergence hypothesis

\begin{tabular}{|c|c|c|c|c|c|}
\hline & \multicolumn{2}{|l|}{ CHINA } & JAPAN & ASEAN+3 & \multirow{2}{*}{ DEV. ASIA } \\
\hline \multicolumn{5}{|c|}{ i) With no autocorrelation } & \\
\hline Indonesia & $-0.09(-0.19$ & $0.05)$ & $0.01(-0.07,0.10)$ & $-0.03 \quad(-0.11,0.08)$ & $-0.01 \quad(-0.09,0.09)$ \\
\hline China & $\mathrm{XXX}$ & & $-0.14^{* * *}(-0.22,-0.06)$ & $-0.02 \quad(-0.09,0.08)$ & $0.00(-0.07,0.09)$ \\
\hline Hong Kong & $-0.02(-0.11$ & $0.09)$ & $-0.12^{* *}(-0.17,-0.05)$ & $0.01(-0.05,0.10)$ & $-0.04(-0.12,0.05)$ \\
\hline India & $-0.02(-0.11$ & $0.09)$ & $0.05(-0.02,0.14)$ & $-0.01 \quad(-0.08,0.09)$ & $0.00 \quad(-0.07,0.09)$ \\
\hline Japan & $-0.02(-0.10$ & $0.08)$ & $\mathrm{XXX}$ & $-0.01 \quad(-0.09,0.08)$ & $-0.06 \quad(-0.15,0.03)$ \\
\hline Taipei & $-0.02(-0.12$ & $0.13)$ & $-0.06(-0.16, \quad 0.10)$ & $0.03 \quad(-0.07,0.16)$ & $-0.03(-0.14,0.12)$ \\
\hline Singapore & $-0.01(-0.09$ & $0.10)$ & $0.01(-0.08,0.12)$ & $-0.04(-0.13,0.08)$ & $-0.08(-0.15,0.00)$ \\
\hline Philippines & $-0.03(-0.12$ & $0.09)$ & $0.01(-0.05,0.09)$ & $0.05 \quad(-0.05,0.19)$ & $-0.02(-0.08,0.11)$ \\
\hline Malaysia & $-0.07(-0.17$ & $0.06)$ & $-0.03(-0.12, \quad 0.08)$ & $-0.01(-0.09,0.08)$ & $-0.01(-0.08,0.08)$ \\
\hline Korea & $0.03(-0.04$ & $0.12)$ & $-0.27(-0.33,0.19)$ & $-0.01(-0.08,0.08)$ & $-0.03(-0.11,0.06)$ \\
\hline \multicolumn{6}{|c|}{ ii) With autocorrelation } \\
\hline Indonesia & $-0.32^{* *}(-0.53$ & $-0.03)$ & $-0.03(-0.13,0.14)$ & $-0.13 \quad(-0.26,0.01)$ & $-0.03 \quad(-0.18,0.12)$ \\
\hline China & $\mathrm{XXX}$ & & $-0.11(-0.23,0.05)$ & $-0.03 \quad(-0.16,0.14)$ & $-0.01 \quad(-0.10,0.18)$ \\
\hline Hong Kong & $-0.11(-0.24$ & $0.05)$ & $0.09(-0.03,0.25)$ & $0.03(-0.06,0.19)$ & $-0.03(-0.15,0.16)$ \\
\hline India & $-0.13(-0.27$ & $0.05)$ & $0.06(-0.05, \quad 0.22)$ & $-0.03 \quad(-0.15,0.12)$ & $0.01 \quad(-0.12,0.18)$ \\
\hline Japan & $-0.06(-0.17$ & $0.09)$ & $\mathrm{XXX}$ & $-0.04 \quad(-0.14,0.13)$ & $-0.07 \quad(-0.16,0.08)$ \\
\hline Taipei & $-0.13(-0.28$ & $0.11)$ & $-0.24(-0.40, \quad 0.00)$ & $0.02 \quad(-0.17,0.25)$ & $0.00 \quad(-0.21,0.45)$ \\
\hline Singapore & $-0.07(-0.10$ & $0.10)$ & $-0.12(-0.23,0.06)$ & $-0.15(-0.28,0.10)$ & $-0.02(-0.12,0.12)$ \\
\hline Philippines & $-0.11(-0.29$ & $0.15)$ & $0.37(0.19, \quad 0.67)^{*}$ & $-0.12(-0.27,0.07)$ & $0.02(-0.15,0.18)$ \\
\hline Malaysia & $-0.21 \quad(-0.37$ & $0.02)$ & $-0.15(-0.26, \quad 0.02)$ & $-0.04(-0.14,0.13)$ & $0.00(-0.12,0.15)$ \\
\hline Korea & $0.07(-0.04$ & $0.21)$ & $-0.17(-0.28,-0.04)$ & $-0.04(-0.15,0.12)$ & $-0.08(-0.21,0.13)$ \\
\hline
\end{tabular}


APPENDIX (Robustness test)

Table A1: Estimates of $d$ (and $95 \%$ confidence bands) based on white noise errors

\begin{tabular}{|c|c|c|c|}
\hline Series & No terms & An intercept & A linear time trend \\
\hline \multicolumn{4}{|c|}{ Single Country FSI } \\
\hline Indonesia & $0.44(0.37,0.52)$ & $0.24(0.18,0.32)$ & $0.24(0.18,0.33)$ \\
\hline China & $0.28 \quad(0.13,0.40)$ & $0.22(0.17,0.29)$ & $\left.\begin{array}{lll}0.19 & (0.13 & 0.27\end{array}\right)$ \\
\hline Hong Kong & $0.56 \quad(0.49,0.64)$ & $0.56 \quad(0.49,0.64)$ & $0.56 \quad(0.49,0.64)$ \\
\hline India & $0.40 \quad(0.33,0.89)$ & $0.31 \quad(0.24,0.39)$ & $0.31 \quad(0.24,0.40)$ \\
\hline Japan & $0.46(0.39,0.53)$ & $0.35 \quad(0.29,0.42)$ & $0.35(0.29,0.42)$ \\
\hline Taipei & $0.39 \quad(0.33,0.46)$ & $0.39 \quad(0.34,0.46)$ & $0.37 \quad(0.31,0.44)$ \\
\hline Singapore & $0.44 \quad(0.38,0.52)$ & $0.39 \quad(0.33,0.47)$ & $0.40 \quad(0.33,0.48)$ \\
\hline Philippines & $0.52(0.44,0.61)$ & $0.53(0.44,0.61)$ & $0.52(0.44,0.61)$ \\
\hline Malaysia & $0.41 \quad(0.34,0.49)$ & $0.26 \quad(0.19,0.35)$ & $0.27 \quad(0.20,0.35)$ \\
\hline Korea & $0.46(0.41,0.53)$ & $0.46 \quad(0.40,0.54)$ & $0.46 \quad(0.40,0.54)$ \\
\hline \multicolumn{4}{|c|}{ Regional FSI Index } \\
\hline Asean-3 & $0.56(0.50,0.63)$ & $0.51 \quad(0.45,0.59)$ & $0.51 \quad(0.45,0.59)$ \\
\hline Developing Asia & $0.61 \quad(0.55,0.69)$ & $0.57 \quad(0.51,0.65)$ & $0.57 \quad(0.51,0.65)$ \\
\hline
\end{tabular}

The values in parenthesis are the $95 \%$ confidence intervals of the non-rejection values of $\mathrm{d}$ using Robinson (1994). In both, the most appropriate model according to the deterministic terms. 
Table A2: Estimates of $d$ (and 95\% confidence bands) based on autocorrelation

\begin{tabular}{|c|c|c|c|c|c|c|}
\hline Series & \multicolumn{2}{|c|}{ No terms } & \multicolumn{2}{|c|}{ An intercept } & \multicolumn{2}{|c|}{ A linear time } \\
\hline Indonesia & 0.61 & $(0.50,0.70)$ & 0.37 & $(0.22,0.55)$ & 0.36 & $(0.23,0.56)$ \\
\hline China & 0.52 & $(0.34,0.67)$ & 0.30 & $(0.22,0.40)$ & 0.26 & $(0.16,0.39)$ \\
\hline Hong Kong & 0.65 & $(0.51,0.80)$ & 0.65 & $(0.51,0.82)$ & 0.65 & $(0.52,0.82)$ \\
\hline India & 0.53 & $(0.40,0.66)$ & 0.36 & $(0.23,0.53)$ & 0.39 & $(0.24,0.54)$ \\
\hline Japan & 0.65 & $(0.54,0.80)$ & 0.51 & $(0.40,0.68)$ & 0.52 & $(0.41,0.68)$ \\
\hline Taipei & 0.75 & $(0.55,0.96)$ & 0.68 & $(0.53,0.90)$ & 0.67 & $(0.53,0.90)$ \\
\hline Singapore & 0.65 & $(0.53,0.74)$ & 0.57 & $(0.42,0.78)$ & 0.60 & $(0.42,0.79)$ \\
\hline Philippines & 0.59 & $(0.42,0.76)$ & 0.58 & $(0.44,0.77)$ & 0.57 & $(0.44,0.77)$ \\
\hline Malaysia & 0.62 & $(0.51,0.78)$ & 0.39 & $(0.25,0.58)$ & 0.41 & $(0.25,0.59)$ \\
\hline Korea & 0.71 & $(0.58,0.85)$ & 0.72 & $(0.58,0.89)$ & 0.72 & $(0.58,0.89)$ \\
\hline \multicolumn{7}{|c|}{ Regional FSI Index } \\
\hline Asean-3 & 0.85 & $(0.70,1.02)$ & 0.75 & $(0.61,0.94)$ & 0.75 & $(0.61,0.94)$ \\
\hline Developing Asia & 0.81 & $(0.67,0.99)$ & 0.78 & $(0.65,0.97)$ & 0.78 & $(0.65,0.97)$ \\
\hline
\end{tabular}


Table A3: Estimates of $\mathbf{d}$ in the convergence against CHINA

\begin{tabular}{|c|c|c|c|}
\hline Series & No terms & An intercept & A linear time trend \\
\hline Indonesia & $0.10 \quad(-0.04,0.19)$ & $0.10(-0.04,0.19)^{*}$ & $0.10 \quad(-0.04,0.19)$ \\
\hline Hong Kong & $0.24 \quad(0.18,0.32)$ & $0.24 \quad(0.17,0.31)$ & $0.23(0.18,0.31)$ \\
\hline India & $0.13(-0.01,0.21)$ & $0.13(-0.01,0.20)^{*}$ & $0.13 \quad(-0.02,0.21)$ \\
\hline Japan & $0.29 \quad(0.23,0.36)$ & $0.29(0.23,0.36)$ & $0.29(0.23,0.36)$ \\
\hline Taipei & $0.21 \quad(0.15,0.28)$ & $0.20 \quad(0.14,0.27)$ & $0.18(0.11,0.25)$ \\
\hline Singapore & $0.15(0.09,0.22)$ & $0.14(0.08,0.22)$ & $0.15(0.09,0.22)$ \\
\hline Philippines & $0.28 \quad(0.21,0.17)$ & $0.29(0.21,0.37)$ & $0.28 \quad(0.21,0.37)$ \\
\hline Malaysia & $0.09 \quad(-0.02,0.21)$ & $0.08 \quad(-0.04,0.17)$ & $0.07(-0.01,0.16)^{*}$ \\
\hline Korea & $0.39 \quad(0.32,0.47)$ & $0.39(0.30,0.47)$ & $0.39 \quad(0.32,0.47)$ \\
\hline
\end{tabular}


Table A4: Estimates of $d$ in the convergence against JAPAN

\begin{tabular}{|c|c|c|c|}
\hline Series & No terms & An intercept & A linear time trend \\
\hline Indonesia & $0.18(0.10,0.26)$ & $0.17(0.09,0.24)$ & $0.17(0.09,0.24)$ \\
\hline China & $0.09(-0.05,0.16) *$ & $0.09(-0.04,0.15)$ & $0.09(-0.04,0.15)$ \\
\hline Hong Kong & $0.07(-0.13,0.16)^{*}$ & $0.07(-0.13,0.15)$ & $0.07(-0.13,0.15)$ \\
\hline India & $0.08(-0.03,0.12)^{*}$ & $0.10(-0.02,0.16)$ & $0.10(-0.02,0.16)$ \\
\hline Taipei & $0.29(0.24,0.35)$ & $0.28(0.21,0.34)$ & $0.28(0.21,0.34)$ \\
\hline Singapore & $0.06(-0.11,0.14)$ & $0.05(-0.10,0.14)^{*}$ & $0.05(-0.10,0.14)$ \\
\hline Philippines & $0.34(0.26,0.43)$ & $0.32(0.23,0.40)$ & $0.32(0.23,0.40)$ \\
\hline Malaysia & $0.12(0.06,0.20)$ & $0.12(0.06,0.20)$ & $0.12(0.06,0.20)$ \\
\hline Korea & $0.11(-0.01,0.20)^{*}$ & $0.12(0.00,0.20)$ & $0.12(-0.01,0.18)$ \\
\hline
\end{tabular}

Table A5: Estimates of $d$ in the convergence against ASEAN-3

\begin{tabular}{|c|c|c|c|}
\hline Series & No terms & An intercept & A linear time trend \\
\hline Indonesia & $0.30 \quad(0.24,0.37)$ & $0.30 \quad(0.24,0.36)$ & $0.27 \quad(0.24,0.33)$ \\
\hline China & $0.17 \quad(0.11,0.25)$ & $-0.02 \quad(-0.09,0.08)$ & $-0.02(-0.09,0.08)^{*}$ \\
\hline Hong Kong & $0.36 \quad(0.29,0.45)$ & $0.36 \quad(0.29,0.45)$ & $0.36 \quad(0.29,0.45)$ \\
\hline India & $0.06 \quad(-0.02,0.12)$ & $0.06(-0.02,0.12)^{*}$ & $0.06 \quad(-0.02,0.12)$ \\
\hline Japan & $0.08 \quad(-0.01,0.14)$ & $0.07(-0.02,0.14)^{*}$ & $0.07 \quad(-0.02,0.14)$ \\
\hline Taipei & $0.30 \quad(0.24,0.37)$ & $0.30 \quad(0.24,0.37)$ & $0.30 \quad(0.24,0.37)$ \\
\hline Singapore & $0.20 \quad(0.13,0.29)$ & $0.20(0.13,0.29)$ & $0.20 \quad(0.13,0.29)$ \\
\hline Philippines & $0.42 \quad(0.35,0.49)$ & $0.42 \quad(0.35,0.49)$ & $0.42 \quad(0.35,0.49)$ \\
\hline Malaysia & $0.05 \quad(-0.03,0.15)$ & $0.05(-0.04,0.14)^{*}$ & $0.05 \quad(-0.03,0.15)$ \\
\hline Korea & $0.27 \quad(0.21,0.35)$ & $-0.01(-0.09,0.08)$ & $-0.02(-0.08,0.08)$ \\
\hline
\end{tabular}

The values in parenthesis are the $95 \%$ confidence intervals of the non-rejection values of $\mathrm{d}$ using Robinson (1994). In both, the most appropriate model according to the deterministic terms. *: Evidence of I(0) behaviour. 
Table A6: Estimates of $d$ in the convergence against DEVELOPING ASIA

\begin{tabular}{|c|c|c|c|}
\hline Series & No terms & An intercept & A linear time trend \\
\hline Indonesia & $0.36 \quad(0.30,0.43)$ & $0.36 \quad(0.30,0.43)$ & $0.36 \quad(0.30,0.43)$ \\
\hline China & $0.29 \quad(0.23,0.37)$ & $0.29 \quad(0.23,0.37)$ & $0.29 \quad(0.22,0.32)$ \\
\hline Hong Kong & $0.36 \quad(0.28,0.43)$ & $0.36 \quad(0.28,0.43)$ & $0.35 \quad(0.27,0.42)$ \\
\hline India & $0.12(-0.01,0.31)$ & $0.10(-0.02,0.21)^{*}$ & $0.09 \quad(-0.03,0.09)$ \\
\hline Japan & $0.14 \quad(0.00,0.33)$ & $0.14(0.01,0.23)^{*}$ & $0.10 \quad(-0.03,0.13)$ \\
\hline Taipei & $0.34 \quad(0.29,0.41)$ & $0.34 \quad(0.29,0.41)$ & $0.34 \quad(0.29,0.41)$ \\
\hline Singapore & $0.07 \quad(-0.01,0.16)$ & $-0.07(-0.13,0.01)^{*}$ & $-0.08(-0.15,0.00)$ \\
\hline Philippines & $0.32 \quad(0.25,0.41)$ & $0.32(0.25,0.41)$ & $0.31 \quad(0.26,0.40)$ \\
\hline Malaysia & $0.28 \quad(0.21,0.46)$ & $0.28 \quad(0.21,0.46)$ & $0.28 \quad(0.21,0.45)$ \\
\hline Korea & $0.23 \quad(0.17,0.41)$ & $0.23(0.17,0.41)$ & $0.23(0.17,0.41)$ \\
\hline
\end{tabular}

